This manuscript has been submitted for publication in Tectonics. Please note that, despite being peerreviewed, the manuscript has yet to be formally accepted for publication. Subsequent versions of this manuscript may have slightly different content. If accepted, the final version of this manuscript will be available via the 'Peer-reviewed Publication DOI' link on the right-hand side of this webpage. Please feel free to contact any of the authors; we welcome feedback. 


\section{Tectonostratigraphy of the northern Okavango Delta and Rift Zone, Botswana}

Vanshan Wright ${ }^{1,5}$, J. Pablo Canales ${ }^{1}$, Nicole d'Entremont ${ }^{1}$, Kitso Matende ${ }^{2}$, Lucky Moffat ${ }^{2}$, Liviu Giosan ${ }^{1}$, Kebabonye Laletsang ${ }^{2}$, Read Mapeo $^{2}$, Mark D. Behn ${ }^{3}$, Sarah Ivory4 4,6

${ }^{1}$ Department of Geology \& Geophysics, Woods Hole Oceanographic Institution, Woods Hole, 02543, Massachusetts, USA

${ }^{2}$ Department of Geology, University of Botswana, Private Bag UB00704, Gaborone, Botswana

${ }^{3}$ Department of Earth \& Environmental Sciences, Boston College, Chestnut Hill, 02467, Massachusetts, USA

${ }^{4}$ Department of Geosciences, Penn State University, University Park, 16801, Pennsylvania, USA

${ }^{5}$ Scripps Institution of Oceanography, University of California San Diego, La Jolla, 92037, California, USA

${ }^{6}$ Earth and Environmental Systems Institute, Penn State University, University Park, 16801, Pennsylvania, USA

Corresponding author: Vanshan Wright (vwright@whoi.edu)

\section{Key Points:}

- First waterborne seismic-reflection profiles within Earth's youngest rift zone (Okavango Rift Zone) shows that it is at least $150 \mathrm{~km}$ wide

- The northernmost mapped fault (i.e., Gumare fault) extends across the Okavango Delta and is in the Okavango Rift Zone

- Tectonic and sediment deformation increases southeastward within the Okavango Rift Zone 


\section{Abstract}

The Okavango Rift Zone (ORZ) and Okavango Delta in Northwest Botswana are Earth's youngest continental rift system and largest inland delta. The delta and its underlying sediments record the effects of incipient rifting on the geomorphology and stratigraphy within the (incipient) southwestern arm of the East African Rift System in Botswana. Three open questions that we use river-borne seismic-reflection profile analyses to answer are (1) whether the Gumare fault extends across the delta, (2) whether the Gumare fault zone is a part of the ORZ, and (3) how wide is the ORZ. Our results suggest that the Gumare fault extends across the delta and is a part of the ORZ. Integration of our and pre-existing geophysical data also suggests that the southern section of the ORZ is more active than the northern section that we imaged, and at least $150 \mathrm{~km}$ of fault-related extension has occurred within the Okavango Rift Zone. These findings provide constraints on the present-day structural and stratigraphic configuration of the ORZ and $\mathrm{OD}$, which is a fundamental first step towards reconstructing sedimentation and extensional patterns during the earliest stages of continental rifting.

\section{Introduction}

The Okavango Delta (OD) is located in the semi-arid landscape of northwestern Earth's youngest continental rift zone, the Okavango Rift Zone (ORZ) (Figures 1-2). This rift zone forms part of the southwestern branch of the East African Rift System (EARS) (Fairhead and Girdler, 1969; Reeves, 1972; Scholz et al., 1976; Chorowicz, 2005). The OD is the largest inland delta and supports several delicate ecosystems and freshwater reservoirs that are vital to the survival and way of life of humans and animals in the region (e.g., McCarthy et al., 1997; Ross, 2003; Wolski and Savenjie, 2006; Mendelson et al., 2010) (Figure 2). Active faulting within the ORZ controls the flow and location of many of the major water bodies within the delta and adjacent areas (e.g., the Zambezi River, Kwando River, Chobe River, Boteti River, Lake Ngami), making the delta a dramatic example of how rifting influences hydrography, sedimentation, human activities, and distribution of vegetation in the region (e.g., Thomas and Shaw, 1991; Moore and Larkin, 2001; Mendelson et al., 2010) (Figure 2). Understanding the linkages and feedback between rifting and the other surface processes requires constraining the present-day structural and stratigraphic configuration of the ORZ and OD infill, which is a fundamental first step towards reconstructing sedimentation and extensional patterns during the earliest stages of continental rifting.

The ORZ is thought to be developing a half-graben structure (e.g., McCarthy et al., 1993; Modisi et al., 2000; Kinabo et al., 2007), a rifting geometry common along the EARS (e.g., Rosendahl, 1987). Some of the major ORZ faults and their characteristics have been determined from high-resolution digital terrain models (Modisi, 2000; Modisi et al., 2000; Kinabo et al., 2007; Kinabo et al., 2008), but many aspects of the ORZ faulting patterns, in particular, their subsurface geometry, remain unknown. Differences in fault characteristics between the center of the rift and the outer margins indicate extended fault histories accompanied by sediment accumulation (Kinabo et al., 2008). Specifically, the rift has been growing in width by transferring motion to younger faults along the outer margins while abandoning older faults in the middle (Kinabo et al., 2008). But the width of the rift is unconstrained, and no evidence has been found yet to support the presence of a fully developed half-graben (Kinabo et al., 2007). 
Geophysical and sedimentological constraints on the tectonostratigraphy and tectonic geomorphology of the OD and ORZ are also limited, deriving only from a few sedimentological studies as well as spatially limited ground-based geophysical transects and aeromagnetic surveys (Greenwood and Carruthers, 1973; Hutchins et al., 1976; de Beer et al., 1979; Modisi et al., 2000; Kinabo et al., 2007; Laletsang et al., 2007; Bufford et al., 2012; Podgorski et al., 2013; Meier et al., 2014; Reiser et al., 2014; Kalscheuer et al., 2015; Podgorski et al., 2015). These data and surveys provide some context on sediment infill properties and general depth to the basement but are inadequate to address the outstanding questions about the rift geometry and evolution.

This paper analyzes new high-resolution seismic-reflection profiles acquired across the northwestern part of the OD to investigate the stratigraphy and faulting characteristics in this part of the delta. Our results suggest that (1) the Gumare fault extends across the delta, making this fault part of the ORZ and probably defining its northwestern limit, (2) faulting influences the stratigraphy within northwestern OD, and (3) the cross-section of the ORZ is at least $150 \mathrm{~km}$, making Earth's youngest continental rift zone active, shallow, and wide.

\section{Tectonic Setting}

The ORZ is an inter-cratonic rift zone developed on the eastern edge of the AngolanCongo craton in Botswana, to the northwest of the Zimbabwe and Kaapvaal cratons (Modisi et al., 2000; Kinabo et al., 2007; Kinabo et al., 2008; Mapeo et al., 2019) (Figure 1). Precambrian crystalline rocks outcrop at several locations along the southern edge of the delta and is surrounded by unconsolidated Kalahari sands (Figure 2). The Precambrian units comprise rocks forming the northeast-trending northern arm of the Damara Belt, which unconformably overlays Neoarchean and Neoproterozoic basement granitoid gneisses (Carney et al., 1994; Singletary et al., 2003; Mapeo et al., 2006; Mapeo et al., 2019). The region also hosts the northeast-trending Ghanzi-Chobe Belt (Carney et al., 1994; Singletary et al., 2003) and the northeast-trending northwestern section of the Botswana Rift (Schwartz et al., 1996; Key and Mapeo, 1999). The northwest-trending Karoo Dyke Swarms on the southern end of the OD are cut by the northeasttrending southern border faults within the ORZ (Modisi et al., 2000).

Elevated seismicity along northeast-trending normal faults, including a $\mathrm{M}_{\mathrm{L}} 6.7$ event in 1952 (Gane and Oliver, 1953), implies that active rifting is ongoing in the ORZ, which is thought to be a southward extension of the EARS (Reeves, 1972; Scholz et al., 1976). The exact age of rifting in the ORZ is not known. Paleoenvironmental reconstruction from sediments collected in Lake Ngami suggests that feeder rivers promoted extensive flow beyond the Thamalakane and Kunyere faults (Figure 2) into the PaleoMakgadikgadi Pans to the southeastern sections of the delta circa $20 \mathrm{ka}$ (Huntsman-Mapila et al., 2006). Between $120 \mathrm{ka}$ and $40 \mathrm{ka}$, tectonic activity resulted in uplift and displacement along the northeast-southwest trending faults resulting in the impoundment of the proto-Okavango, Kwando, and the upper Zambezi rivers and the development of the proto-Makgadikgadi, Ngami, and Mababe sub-basins (Cooke, 1984; Thomas and Shaw, 1991; Moore and Larkin, 2001; Ringrose et al., 2005). Thus, rifting in the Okavango may have been initiated about 40,000 years ago, making the ORZ Earth's youngest known continental rift. As rifting developed during the last several tens of thousands of years, the OD formed as faulting dammed and diverted the Okavango river (e.g., Morley, 2002). Since then, the 
delta has preserved a unique record of how rift basins form and modulate the sedimentation and geomorphologic patterns within the region (e.g., Morley, 2002).

In the OD, clastic sediments (primarily fine sand intercalated with silts and clays) dominate exposed sections of the upper delta, while silcrete and calcrete chemical sediments dominate the delta's distal portions (Gumbricht et al., 2001). The depth to the ORZ basement and fault geometries have been sparsely inferred from seismicity, seismic refraction, and electromagnetic surveys, and the basement has been imaged at a few locations from short, landbased seismic reflection profiles (Greenwood and Carruthers, 1973; Hutchins et al., 1977; de Beer et al., 1979; Modisi et al., 2000; Kinabo et al., 2007; Laletsang et al., 2007; Bufford et al., 2012; Podgorski et al., 2013; Meier et al., 2014; Reiser et al., 2014; Kalscheuer et al., 2015; Podgorski et al., 2015). Total sediment thickness above the crystalline basement is between 200 $\mathrm{m}$ and $800 \mathrm{~m}$ (Meier et al., 2014; Reiser et al., 2014; Kalscheuer et al., 2015; Podgorski et al., 2015). Surveys within the southeastern section of the OD reveal: (1) an upper heterogeneous unit corresponding to a modern delta composed of dry and freshwater-saturated sand and lesser amounts of clay and silt, and characterized by moderate to high resistivity, very low to low Vp, and is seismically non-reflective, (2) a unit of low resistivity, low $\mathrm{Vp}$, and strong subhorizontal reflectors consisting of saline-water saturated sands and clays deposited in the MPL, (3) a unit of freshwater-saturated deposits corresponding to the Okavango paleo-megafan beneath the northern part of the modern delta, (4) an interface between the MPL and the reflective basement at 90-235 m depth (Meier et al., 2014; Reiser et al., 2014; Kalscheuer et al., 2015; Podgorski et al., 2015). Because there are no known surveys (to our knowledge) within the northwestern OD, it is unclear whether the stratigraphy of the northwestern and southeastern sections of the region is similar.

At least ten major faults deform the sediments above the basement. From northwest to southeast, the names of the faults are the Gumare, Linyanti, Tsau, Chobe, Lecha, Kunyere, Mababe, Thamalakane, and Phuti faults (Kinabo et al., 2007; Kinabo et al., 2008) (Figure 2). Modisi et al., (2000) hypothesize that the Kunyere fault is the border fault. In contrast, Kinabo et al., (2008) propose that a more extensive border fault is developing via southeastward fault propagation linkages between the Kunyere-Thamalakane-Mababe fault systems (Figure 2). The Gumare fault, located $\sim 100 \mathrm{~km}$ from the nearest known major ORZ fault (Tsau and Chobe faults), is suspected to represent the northwestern extent of the ORZ (Modisi, 2000). This interpretation would suggest that the ORZ cross-sectional area is at least $150 \mathrm{~km}$ wide (Kinabo et al., 2008). However, the Gumare fault is only observed as a lineament in digital terrain models west of the OD (Kinabo et al., 2007; Kinabo et al., 2008). Aeromagnetic data suggest that the Gumare fault only partially truncates a west-northwest-trending 180 Ma Karoo dike swarm that cuts through the southwestern section of the OD (Modisi et al., 2000). This raises the question that the Gumare fault may not extend across the OD, and it may not be a rift-related feature. Answering this question and determining whether there are other major faults between the Gumare and Tsau faults would have significant implications for understanding the formation and earliest evolution of the ORZ.

\section{Methods}

We constrain the tectonostratigraphy beneath the northwestern section of the OD by interpreting $\sim 214 \mathrm{~km}$ of seismic reflection profiles collected in October 2019, along two river 
systems that incise the delta (Figure 2, 3). To date, we have been unable to continue our surveys through the southern section of the delta because COVID-19 is real, and the related local and international travel restrictions are still in place. Future surveys through the central and southeastern parts of the delta are planned for when conditions improve.

We collected the seismic-reflection profiles with a portable, low-frequency acoustic system (HMS-620 Bubble Gun $^{\mathrm{TM}}$ ) that can provide deep bottom penetration through sediments whose grain sizes range from silts to gravels. The seismic source is a tow vehicle-mounted electromagnetic transducer that produces acoustic pulses with highly repeatable wavelets in the frequency range of 70-1700 Hz (Figure 4). A 2300-Watt inverter generator and an aluminumhull 7-m long boat powered and towed the HMS-620 Bubble Gun ${ }^{\mathrm{TM}}$. The source was triggered every 0.5 milliseconds, and the boat speed varied between 2-5 knots depending on environmental conditions. The receiver (MicroEel analog streamer) contains 24 hydrophones spaced $0.11 \mathrm{~m}$ apart. Each hydrophone has a flat frequency response spectrum between 10-10000 Hz. We used a GPS to constrain shot and receiver positions.

We enhanced coherent seismic signals using a bandpass filter (30-50-3000-3500 Hz) and Hilbert transform, followed by using reflector termination mapping to identify major seismic horizons, unconformities, and faults. We consider major seismic horizons as the reflections that bound groups of reflections with similar amplitudes, pulse widths, and stratal geometries. Horizon and unconformity tracing enabled us to quantify the thickness, dip, and continuity of the main sedimentary units, which we used (alongside terminations) to determine where faults exist and when faults were active. We integrated our interpretations with the existing OD electromagnetic, electrical resistivity tomography, and seismic refraction survey results, thus providing an improved understanding of the tectonostratigraphic and tectonic geomorphic development of the OD and ORZ with time.

\section{Results}

We identify seismic reflections from an acoustic basement and three overlying sedimentary units despite significant noise within the seismic-reflection profiles (Figures 5-6). The sedimentary units thicken and dip towards the southeast, and several units contain internal terminations. The two-way travel-time and dip of the top of the acoustic basement change along the strike of the rivers. We can use the results to assess relationships between faulting, sedimentation, and delta morphology.

\subsection{Data Quality}

The noise in the seismic-reflection profiles varies with space and travel-time (Figure 5-6). Most seismic-reflection profiles contain a group of relatively high amplitude and broad pulsewidth reflectors within the upper 25-50 milliseconds (Figure 5). These reflectors' amplitudes and pulse-widths decreased when we enhanced the grounding of the generator and transducer and after filtering with Hilbert transform. Total vertical 'wash-outs' of the seismic signals occur along some meander bends (Figures 5-6). Some profiles contain noise introduced by streamer tension when the boat accelerated or decelerated to avoid environmental obstacles (Figures 5-6). In general, noise does not significantly limit the ability to correlate the major seismic horizons between seismic-reflection profiles.

\subsection{Seismic Stratigraphy}


We refer to the four main seismically distinguishable sedimentary units as Units I, II, III, and IV (Figures 5-7). Units with larger roman numerical are stratigraphically deeper.

Unit I is a group of relatively high amplitude reflections with either sub-horizontal, undulatory, chaotic, anastomosing, or prograding seismic reflections that often terminate within the unit (Figures 5-6).

Unit II is mostly acoustically shallow or transparent, with a few sub-horizontal internal reflections in the southeasternmost profiles (Figures 5-6). We did not confidently identify a reflector separating Units I and II.

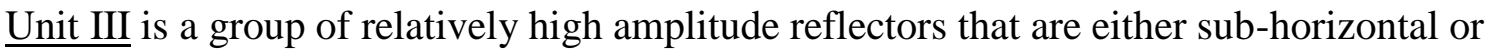
gently undulating (Figures 5-6).

Unit IV is the acoustic basement (i.e., the lowermost resolvable layer). The seismic horizon representing the top of Unit IV is either sub-horizontal or undulating. Unit IV's internal reflections are mainly incoherent; some of the unit's internal reflections dip towards the north (Figures 5-6). The units' stratigraphic depths and thicknesses change (increases or decreases) along the strike of the river, primarily increasing southeastwards (Figure 7).

All units dip southeastwards. There are at least two significant stratigraphic offsets between the horizons representing the tops of Units III. There are at least four significant stratigraphic offsets between horizons representing the tops of Unit IV.

\section{Discussion}

\subsection{Interpretation of the Seismic-Reflection Profiles}

Orogenesis, erosion, rifting, and climatic conditions likely control the stratigraphy and structural deformation within the region. We interpret that the top of Unit IV represents the top of a crystalline basement deformed during Pan African orogenesis, then eroded. Undulatory reflections and the terminated dipping reflections are evidence of erosion, folding, and/or tilting that resulted in an angular unconformity. Orogenesis and erosion are unsurprising since deformed crystalline rocks outcrop beneath the southeasternmost sections of the delta, and we collected the interpreted seismic-reflection profiles within rivers that lie structurally above the Damara Orogenic Belt (Figure 1). Therefore, the top of the Damara Orogenic Belt is likely the top of the acoustic basement in the seismic-reflection profiles.

The changes in reflection characteristics of Unit I-III likely signify changes in depositional conditions. Unit III's parallel seismic-reflection geometry could be broadly interpreted as the result of sediment layering that developed due to fluctuations in sedimentation rates, climate conditions, and sediment type. Unit II's acoustic transparency signifies minimal changes in sediment elastic properties (e.g., density and seismic velocity). This unit likely comprises wind-blown Kalahari sands known to underly fluvio-deltaic sediments within this region (Thomas and Shaw, 1990) (Figure 2). These sands are part of the Kalahari Group sedimentary sequence, which in northern Botswana has a thickness ranging approximately from 30 to $180 \mathrm{~m}$ (Haddon and McCarthy, 2005). Unit I is characterized by fluvio-deltaic facies (i.e., symmetrical, anastomosing, and climbing dunes) evidenced by the unit's sub-horizontal, undulatory, chaotic, anastomosing, and or prograding reflections (Figures 5-6). The internal terminations within this unit signify low seismic coherency, which may occur due to noise, low 
sediment supply, and/or erosion. The lack of significant spatiotemporal changes in the seismicreflection characteristics within this unit suggests that similar geologic processes and/or climate conditions (e.g., Angolan floods) have influenced sedimentation patterns within the unit.

Faulting has deformed and/or is currently deforming Units II-IV. Evidence for faultrelated deformation includes (1) dipping and offsets of the tops of the basement and Unit III and (2) the dipping and thickening/thinning of Units I-III, which signal increases in accommodation space (Figure 7). We tentatively interpret four normal faults at the most significant stratigraphic offsets (Figure 8), recognizing that these are likely single faults in a larger localized shear zone and that there may be additional more minor faults unresolvable by our data. We hypothesize that other faults exist between the northwestern and southeastern seismic-reflection profiles, where we have no data (i.e., between $22.7^{\circ} \mathrm{E}, 19.1^{\circ} \mathrm{S}$ and $22.8^{\circ} \mathrm{E}, 19.0^{\circ} \mathrm{S}$ ) because Units 1 -III become stratigraphically deeper and thicker between the two groups of seismic-reflection profiles. The lack of evidence for fault-related deformation in Unit I may suggest that this unit was deposited after the faults were last active.

\subsection{Comparisons with and extension of previous studies}

Our findings are generally consistent with previous geophysical surveys in the region (Greenwood and Carruthers, 1973; de Beer et al., 1979; Hutchins et al., 1977; Laletsang, 1995; Modisi et al., 2000; Bufford et al., 2012; Podgorski et al., 2013; Kinabo et al., 2007; Laletsang et al., 2007; Meier et al., 2014; Reiser et al., 2014; Kalscheuer et al., 2015; Podgorski et al., 2015). Our interpretation that Unit I comprises fluvio-deltaic sediments is consistent with results from Gumbricht et al. (2001), who describes the uppermost unit as a delta composed of dry and freshwater-saturated sand intercalated with lesser amounts of clay and silt. Previous studies interpreted the underlying two units (i.e., Units II-III) as freshwater-saturated deposits corresponding to the Okavango paleo-megafan. Our data are not sensitive to this, and we found no evidence supporting or refuting this interpretation. The reported low resistivity in Unit II (e.g., Podgorski et al., 2013; Meier et al., 2014; Kalscheuer et al., 2015) is consistent with the general acoustic transparency observed in Unit II. Observations that Unit II contains relatively lowreflective sub-horizontal reflections in a few of the southernmost seismic-reflection profiles (Figure 5-6) might imply that the interpreted Kalahari sands become more layered and or interbedded with clays in the south, as interpreted by previous workers (e.g., Podgorski et al., 2013; Meier et al., 2014; Kalscheuer et al., 2015). If Unit III is indeed a part of the paleomegafan, the fan sediments are layered and deformed by basement faulting (Figures 5-7). Consistent with others who find that the top of the basement is relatively shallow $(200-800 \mathrm{~m}$ below the surface) (e.g., Modisi et al., 2000; Kinabo et al., 2007; Laletsang et al., 2007; Bufford et al., 2012; Podgorski et al., 2013; Kalscheuer et al., 2015; Podgorski et al., 2015), we estimate that the top of the crystalline basement is roughly at $\sim 80-240 \mathrm{~m}$ below the surface, assuming that average compressional wave velocities of Units I-III are $\sim 1900 \mathrm{~m} / \mathrm{s}$ (Reiser et al., 2014).

The above results and interpretations provide answers to three open questions about the geometry of the ORZ -- i.e., (1) whether the Gumare fault extends across the delta, (2) whether the Gumare fault is a part of the ORZ, and (3) how wide is the ORZ. We interpret that the mapped section of the Gumare fault extends across the delta because straight-line projections of the two most extreme trends along the Gumare fault align with a region encompassed by two faults identified in this study exist - the Gumare fault could thus be either of the two faults identified within this study (Figures 2 and 5-7). Interpretations that at least three normal faults 
exist between the Gumare and Tsau faults, alongside observations that sediment thickness and accommodation increase southwards (Figures 4-7; Kinabo et al., 2018), indicate that the previously mapped strand of the Gumare fault is a part of a group of extensional faults that may be less active than the faults in the south. We thus conclude that the Gumare fault is a part of the ORZ, that the ORZ is at least $150 \mathrm{~km}$ wide in cross-section, and that the depth to the top of the faulted basement is shallow across the entire $150 \mathrm{~km}$ cross-section.

\section{Conclusion}

This study represents the first of its kind in collecting and analyzing river-borne seismic reflection profiles across the Okavango Delta and Rift Zone, a dramatic example of how incipient rifting alter and modulate sedimentary and geomorphic patterns within continents. Our interpretations suggest that the Gumare fault extends across the delta, the Gumare fault is a part of the ORZ, faulting influences the stratigraphy within northwestern Okavango Delta, and the Okavango Rift Zone is wide. Although our dataset is limited to the northern part of the Okavango Delta, findings from this study demonstrate the power of river-borne seismicreflection profile analyses to address some critical questions regarding the stratigraphy and structure of the Okavango Rift Zone.

\section{Acknowledgment}

National Science Foundation grant EAR-1714909 supported this project. We are grateful to the Ministry of Minerals, Energy and Water Resources of the Republic of Botswana for granting us the Research Permits to conduct this research and to the Department of Environmental Affairs of the Ministry of Environment, Natural Resources, Conservation, and Tourism of the Republic of Botswana for their Authorization of the Environmental Impact Statement for this project. We thank Loci Environmental Pty Ltd for their environmental impact assessment services. We thank Endeavour Safaris for their logistical and transportation services for our surveys.

\section{References}

Bufford, K. M., E. A. Atekwana, M. G. Abdelsalam, E. M. Shemang, E. A. Atekwana, K. Mickus, M. Moidaki, M. P. Modisi, and L. Molwalefhe (2012), Geometry and faults tectonic activity of the Okavango Rift Zone, Botswana: Evidence from magnetotelluric and electrical resistivity tomography imaging, J. Afr. Earth Sci., 65, 61-71.

Chorowicz, J. (2005), The East African rift system, J. Afr. Earth Sci., 43, 379-410.

Cooke, H. J. (1984), The evidence from northern Botswana of climate change, in Late Cenozoic palaeoclimates of the southern hemisphere, edited by J. Vogel, pp. 265278, Balkema, Rotterdam.

de Beer, J. H., D. I. Gough, and J. S. V. van Zijl (1979), The tectonic significance of geomagnetic induction anomalies in Botswana and Southwest Africa, paper presented at Proceedings of a Seminar on Geophysics and the Exploration of the Kalahari, Botswana Geological Survey.

Fairhead, J. D., and R. W. Girdler (1969), How far does the Rift System extend through Africa?, Nature, 221, 1018-1020. 
Gane, P. G., and H. O. Oliver (1953), South African earthquakes -1949 to December 1952, Transactions of the Geological Society of South Africa, 56, 21-35.

Greenwood, P. D., and R. M. Carruthers (1973), Geophysical Survey in the Okavango Delta, Botswana, Rep., 1-22 pp, Institute of Geological Sciences, London, UK.

Gumbricht, T., T. S. McCarthy, and C. L. Merry (2001), The topography of the Okavango Delta, Botswana, and its tectonic and sedimentological implications, South African Journal of Geology, 104(3), 243-264.

Haddon, I. G., and T. S. McCarthy (2005), The Mesozoic-Cenozoic interior sag basins of Central Africa: The Late-Cretaceous-Cenozoic Kalahari and Okavango basins, J. Afr. Earth Sci., 43, 316-333.

Huntsman-Mapila, P., S. Ringrose, A. W. Mackay, W. S. Downey, M. P. Modisi, S. H. Coetzee, J.-J. Tiercelin, A. B. Kampunzu, and C. van der post (2006), Use of geochemical and biological sedimentary record in establishing palaeoenvironments and climate change in the Lake Ngami basin, NW Botswana, Quaternary International, $148,51-64$.

Hutchins, D. G., R. G. Peart, and P. Herbert (1977), Deep electrical soundings in the Okavango Delta- A trial survey, Rep., Geological Survey Department, Ministry of Mineral Resources and Water Affairs, Botswana.

Kalscheuer, T., S. Blake, J. E. Podgorski, F. Wagner, A. G. Green, H. Maurer, A. G. Jones, M. Muller, O. Ntibinyane, and G. Tshoso (2015), Joint inversions of three types of electromagnetic data explicitly constrained by seismic observations: results from the central Okavango Delta, Botswana, Geophys J. Int., 202, 1-24.

Kinabo, B. D., E. A. Atekwana, J. P. Hogan, M. P. Modisi, and A. B. Kampunzu (2007), Early structural development of the Okavango rift zone, NW Botswana, Journal of African Earth Sciences, 48(2-3), 125-136.

Kinabo, B. D., J. P. Hogan, E. A. Atekwana, M. G. Abdelsalam, and M. P. Modisi (2008), Fault growth and propagation during incipient continental rifting: Insights from a combined aeromagnetic and Shuttle Radar Topography Mission digital elevation model investigation of the Okavango Rift Zone, northwest Botswana, Tectonics, 27, TC3013, doi:10.1029/2007TC002154.

Laletsang, K., M. P. Modisi, E. M. Shemang, L. Moffat, and O. R. Moagi (2007), Shallow seismic refraction and magnetic studies at Lake Ngami, The Okavango Delta, Northwest Botswana, Journal of African Earth Sciences, 48, 95-99.

Mapeo, R. B. M., Ramokate, L. V., Corfu, F., Davis, D. W., and A.B. Kampunzu, (2006). The Okwa basement complex, western Botswana: U-Pb zircon geochronology and implications for Eburnean processes in southern Africa. Journal of African Earth Sciences, 46(3), 253-262. 
McCarthy, T. S., R. W. Green, and N. J. Franey (1993), The influence of neo-tectonics on water dispersal in the northeastern regions of the Okavango swamps, Botswana, Journal of African Earth Sciences, 17(1), 23-32.

McCarthy, T. S., M. Barry, A. Bloem, W. N. Ellery, H. Heister, C. L. Merry, H. Ruther, and H. Sternberg (1997), The gradient of the Okavango fan, Botswana, and its 16 sedimentological and tectonic implications, Journal of African Earth Sciences, 24(1/2), 65-78.

Mendelson, J. M., C. vanderPost, L. Ramberg, M. Murray-Hudson, P. Wolski, and K. Mosepele (2010), Okavango Delta: Floods of Life, 144 pp., research and Information Services of Namibia, Windhoek, Namibia.

Meier, P., T. Kalscheuer, J. E. Podgorski, L. Kgotlhang, A. G. Green, S. Greenhalgh, L. Rabenstein, J. Doetsch, W. Kinzelbach, E. Auken, P. Mikkelsen, N. Foged, B. C. Jaba, G. Tshoso, and O. Ntibinyane (2014), Hydrogeophysical investigations in the western and north-central Okavango Delta (Botswana) based on helicopter and ground-based transient electromagnetic data and electrical resistance tomography, Geophysics, 79(5), B201-B211.

Modisi, M. P. (2000), Fault system at the southeastern boundary of the Okavango Rift, Botswana, J. Afr. Earth Sci., 30(3), 569-578.

Modisi, M. P., E. A. Atekwana, and A. B. Kampunzu (2000), Rift kinematics during the incipient stages of continental extension: Evidence from nascent Okavango rift basin, northwest Botswana, Geology, 28(10), 939-942.

Moore, A. E., and P. Larkin (2001), Drainage evolution in south-central Africa since the breakup of Gondwana, South African Journal of Geology, 104, 47-68.

Morley, C. K. (2002), Evolution of large normal faults: Evidence from seismic reflection data, AAPG Bull., 86(6), 961-978.

Podgorski, J. E., E. Auken, C. Schamper, A. V. Christiansen, T. Kalscheuer, and A. G. Green (2013), Processing and inversion of commercial helicopter time-domain electromagnetic data for environmental assessments and geologic and hydrologic mapping, Geophysics, 78, E149-E159.

Podgorski, J. E., A. G. Green, T. Kalscheuer, W. K. H. Kinzelbach, H. Horstmeyer, H. Maurer, L. Rabenstein, J. Doetsch, E. Auken, T. Ngwisanyi, G. Tshoso, B. C. Jaba, O. Ntibinyane, and K. Laletsang (2015), Integrated interpretation of helicopter and ground-based geophysical data recorded within the Okavango Delta, Botswana, J. App. Geophys., 114, 52-67.

Reeves, C. V. (1972), Rifting in the Kalahari?, Nature, 237, 95-96.

Reiser, F., Podgorski, J.E., Schmelzbach, C., Horstmeyer, H., Green, A.G., Kalscheuer, T., Maurer, H., Kinzelbach, W.K., Tshoso, G. and Ntibinyane, O. (2014), Constraining helicopter electromagnetic models of the Okavango Delta with seismic-refraction and seismic-reflection dataOkavango Delta seismic study. Geophysics, 79(3), B123-B134. 
Ringrose, S., P. Huntsman-Mapila, A. B. Kampunzu, W. Downey, S. Coetzee, B. Vink, W. Matheson, and C. vanderPostvan der Post (2005), Sedimentological and geochemical evidence for palaeo-environmental change in the Makgadikgadi subbasin, in relation to the MOZ rift depression, Botswana, Palaeogeography, Palaeoclimatology, Palaeoecology, 217, 265-287.

Rosendahl, B. R. (1987), Architecture of continental rifts with special reference to East Africa, Ann. Rev. Earth Planet. Sci., 15, 445-453.

Ross, K. (2003), Okavango: Jewel of the Kalahari, 216 pp., Struik Publishers, Cape Town.

Scholz, C. H., T. A. Koczynski, and D. G. Hutchins (1976), Evidence for incipient rifting in Southern Africa, Geophys. J. R. Astron. Soc., 44, 135-144.

Thomas, D. S. G., and P. A. Shaw (1990), The deposition and development of the Kalahari Group sediments, Central Southern Africa, Journal of African Earth Sciences, 10, 187-197.

Thomas, D. S. G., and P. A. Shaw (1991), The Kalahari Environment, 298 pp., Cambridge University Press.

Wolski, P., and H. H. G. Savenjie (2006), Dynamics of floodplain-island groundwater flow in the Okavango Delta, Botswana, Journal of Hydrology, 320(3-4), 283-301. 


\section{Figure Captions}

419 Figure 1. Simplified geological map showing the major orogenic belts, sedimentary basins, and 420 faults of interest within (a) Southern Africa and (b) Botswana. (Modified from Leseane et al., 421 2015).

422 Figure 2. (a) Map showing major faults, sedimentary deposits, igneous rock outcrops, rivers, 423 lakes, vegetation, and locations where we collected seismic-reflection profiles within the 424 Okavango Delta. The figure is modified after and inspired by Bufford et al. (2012) and Kinabo et 425 al. (2008). (b) Cartoon redrawn from McCarthy et al. (1993) illustrating the early concepts of the 426 ORZ being a half-graben. The cartoon is on data collected and compiled by McCarthy et al., 427 (1993).

428 Figures 3. Maps showing the location of (a) all seismic reflection profiles and (b-f) the seismic429 reflection profile images shown in figures 5-6. The numbers on (a) refer to the seismic line 430 numbers, which are highlighted in blue.

431 Figure 4. Photo shows the (a) source and streamer for the HMS-620 Bubble Gun ${ }^{\mathrm{TM}}$ system, the 432 acoustic profiling system to collect the seismic-reflection profiles used in this study. We towed 433 the system with an (b) aluminum hull boat.

434 Figures 5. Examples of seismic-reflection profiles from the northwestern part of our survey. 435 Four major sedimentary units (named Units I-IV) are interpreted and labeled. Line locations are 436 shown in figure 3.

437 Figures 6. Examples of seismic-reflection profiles from the southeastern part of our survey, with 438 four major sedimentary units (named Units I-IV) labeled. Line locations are shown in figure 3.

$439 \quad$ Figure 7. Isochron maps showing two-way travel times for all sedimentary units above the 440 basement, Units I-II, and Unit III.

$441 \quad$ Figure 8. Image showing a three-dimensional rendered view of seismic horizons separating 442 Units I-IV. We identify at least four faults (black lines). 
Figure 1

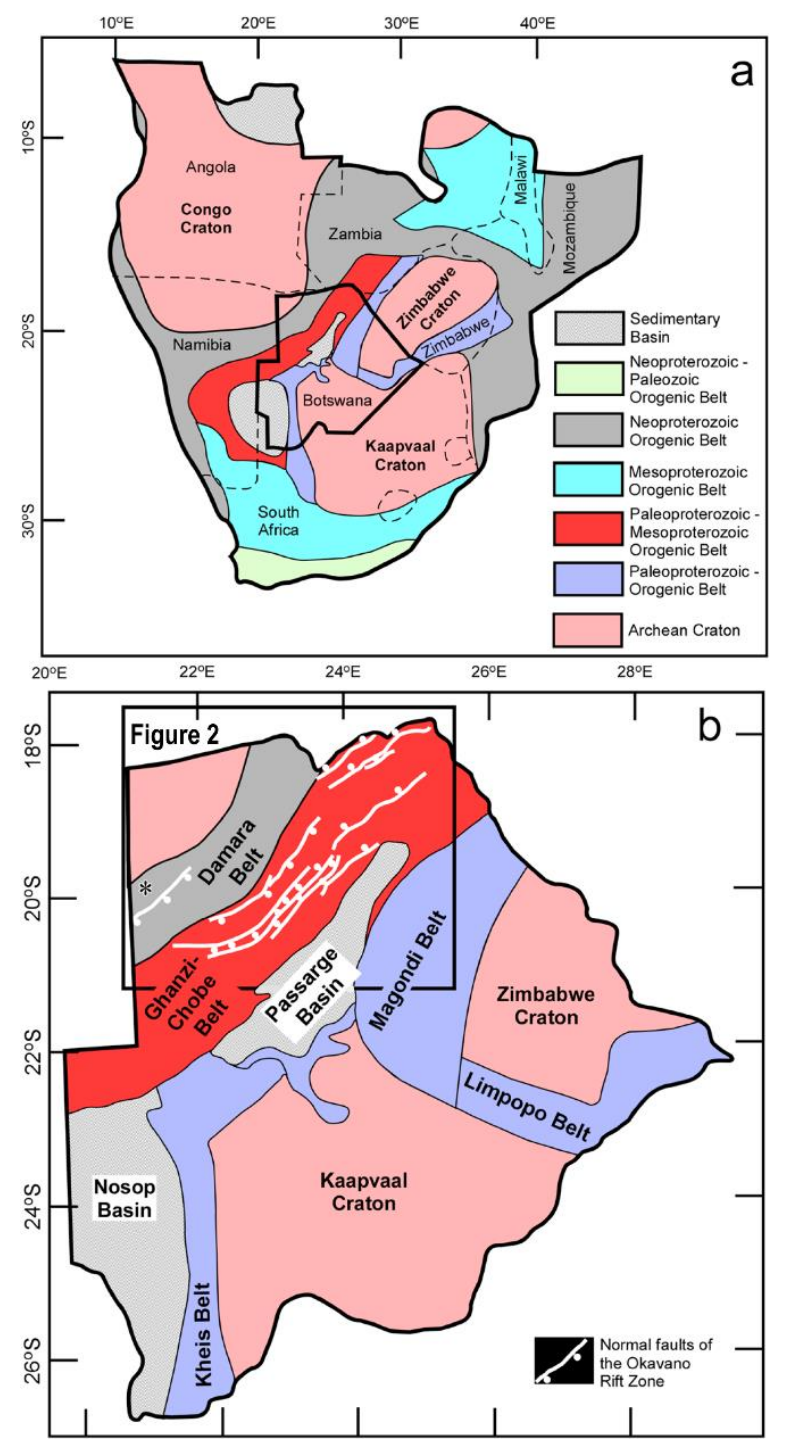


Figure 2

A)
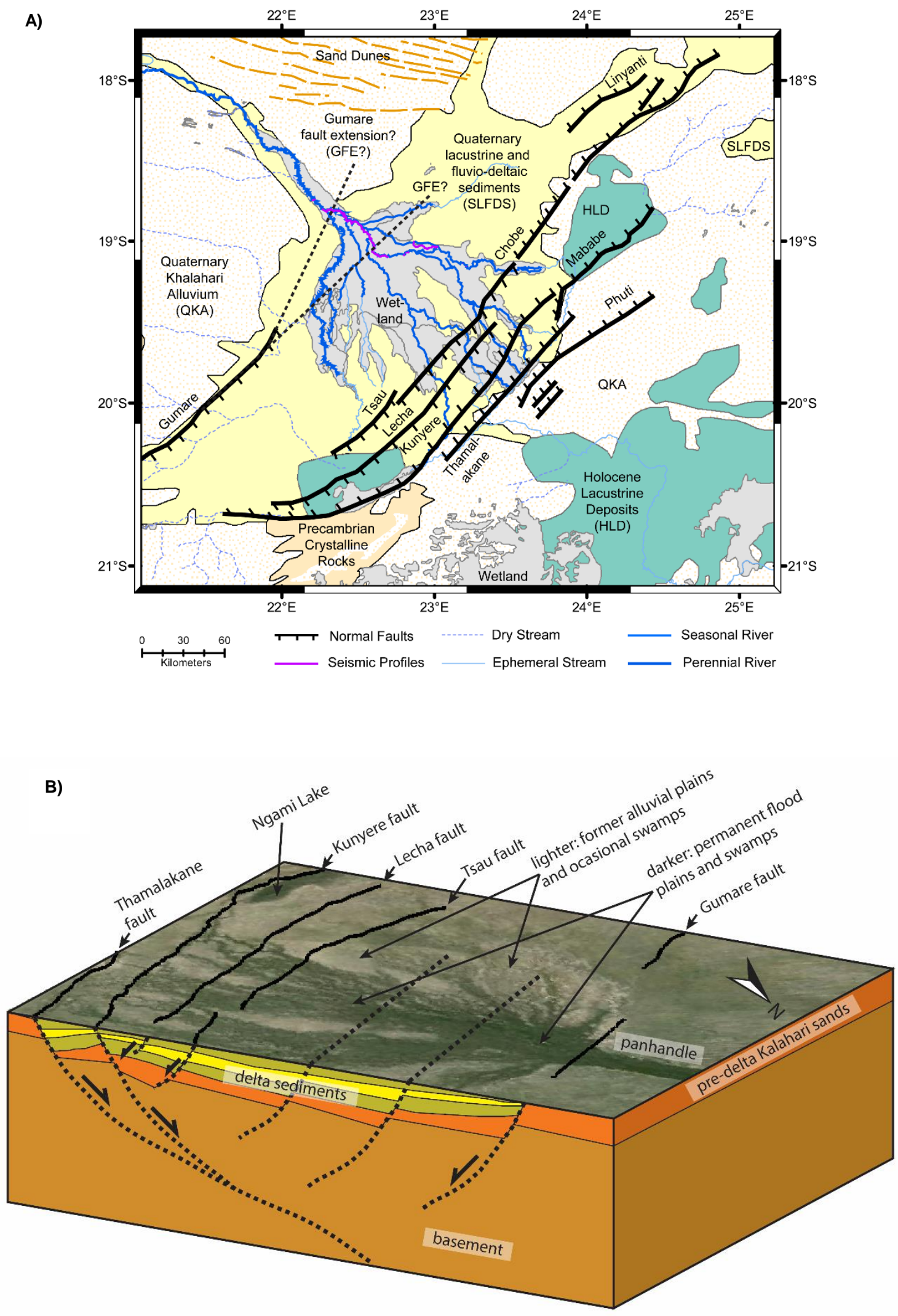
Figure 3
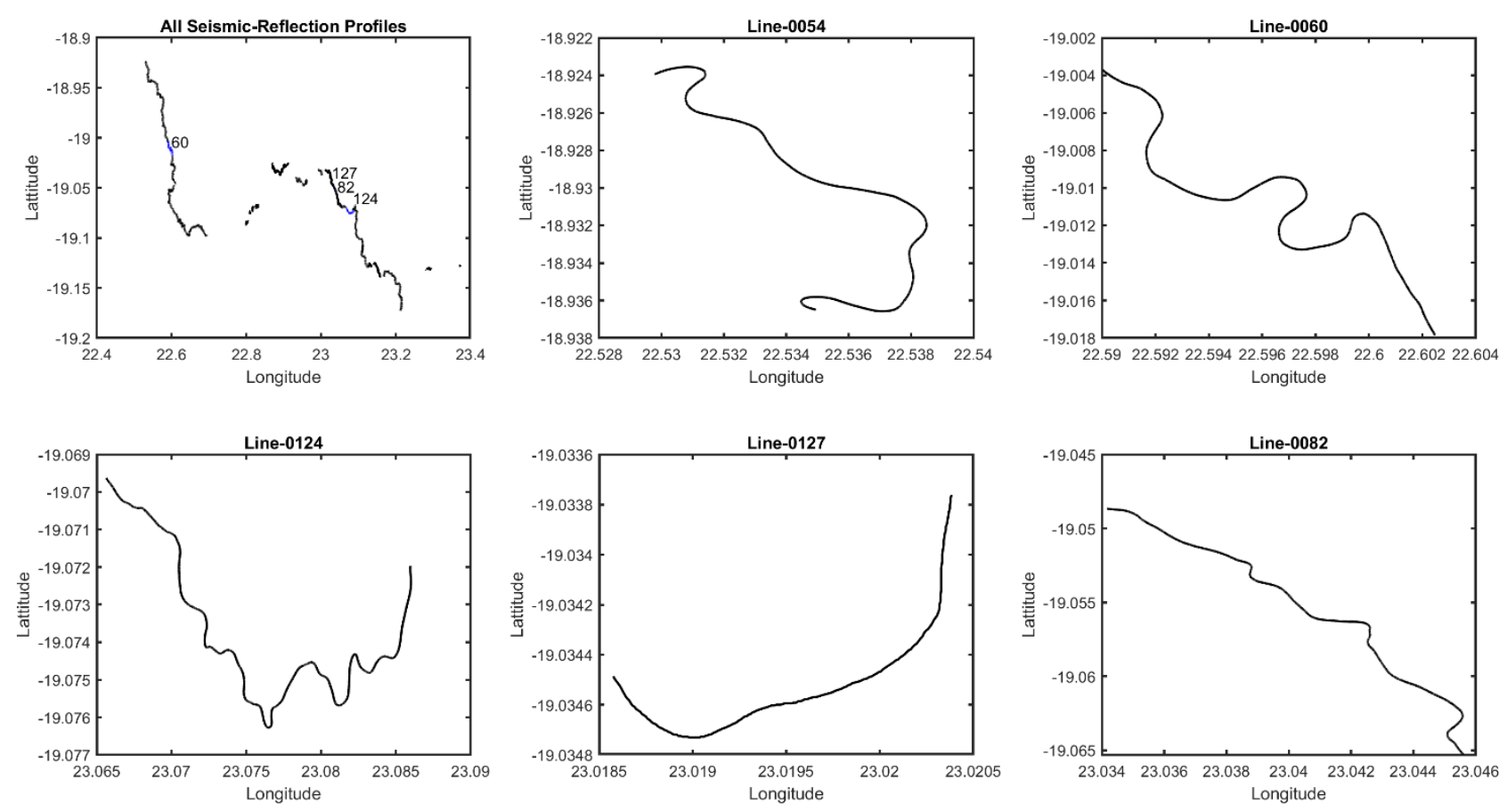
Figure 4

A) HMS-620 Bubble Gun source (top left) and streamer (botton left) on land and in water
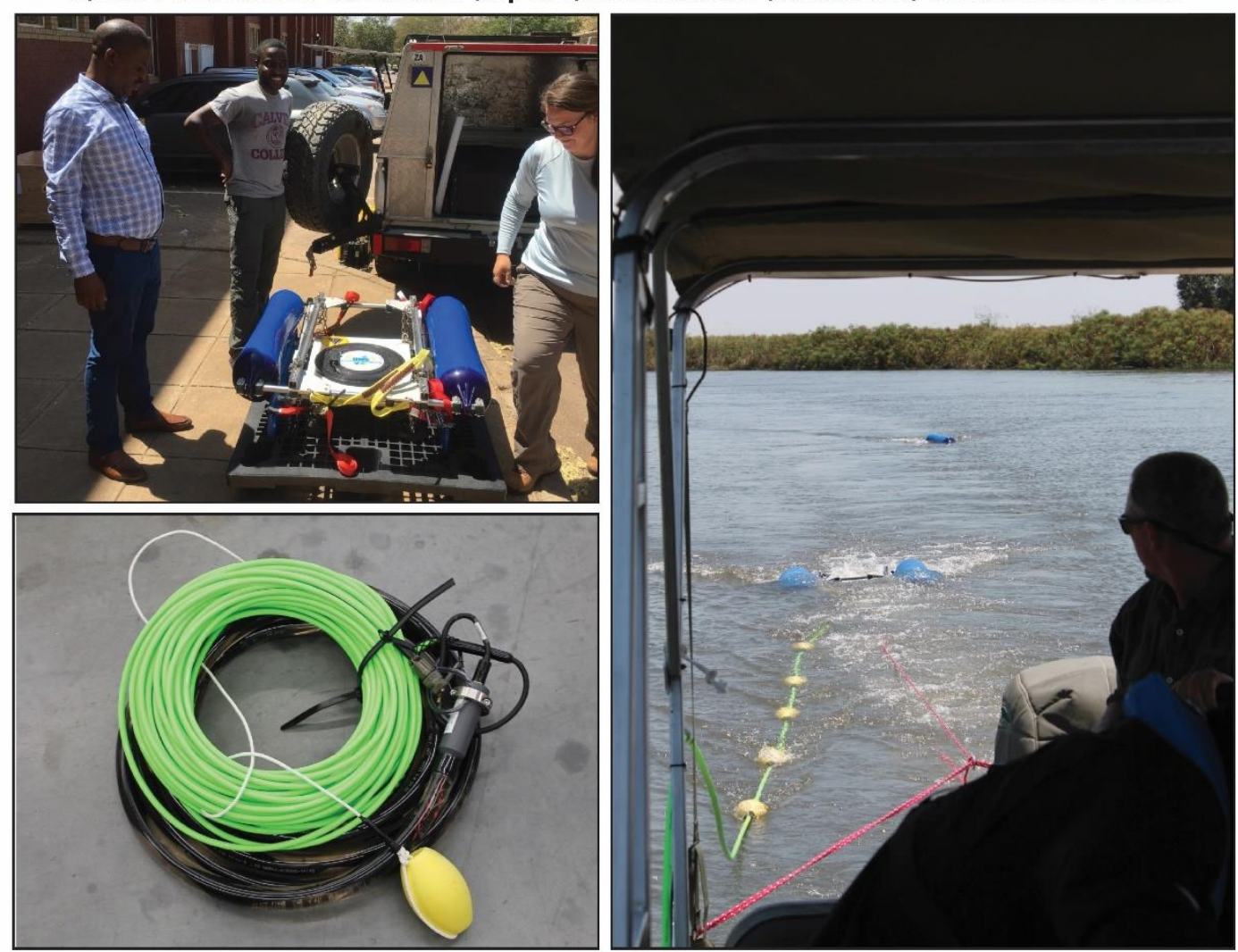

B) Aluminium-Hull Boat used to collect seismic-reflection profiles

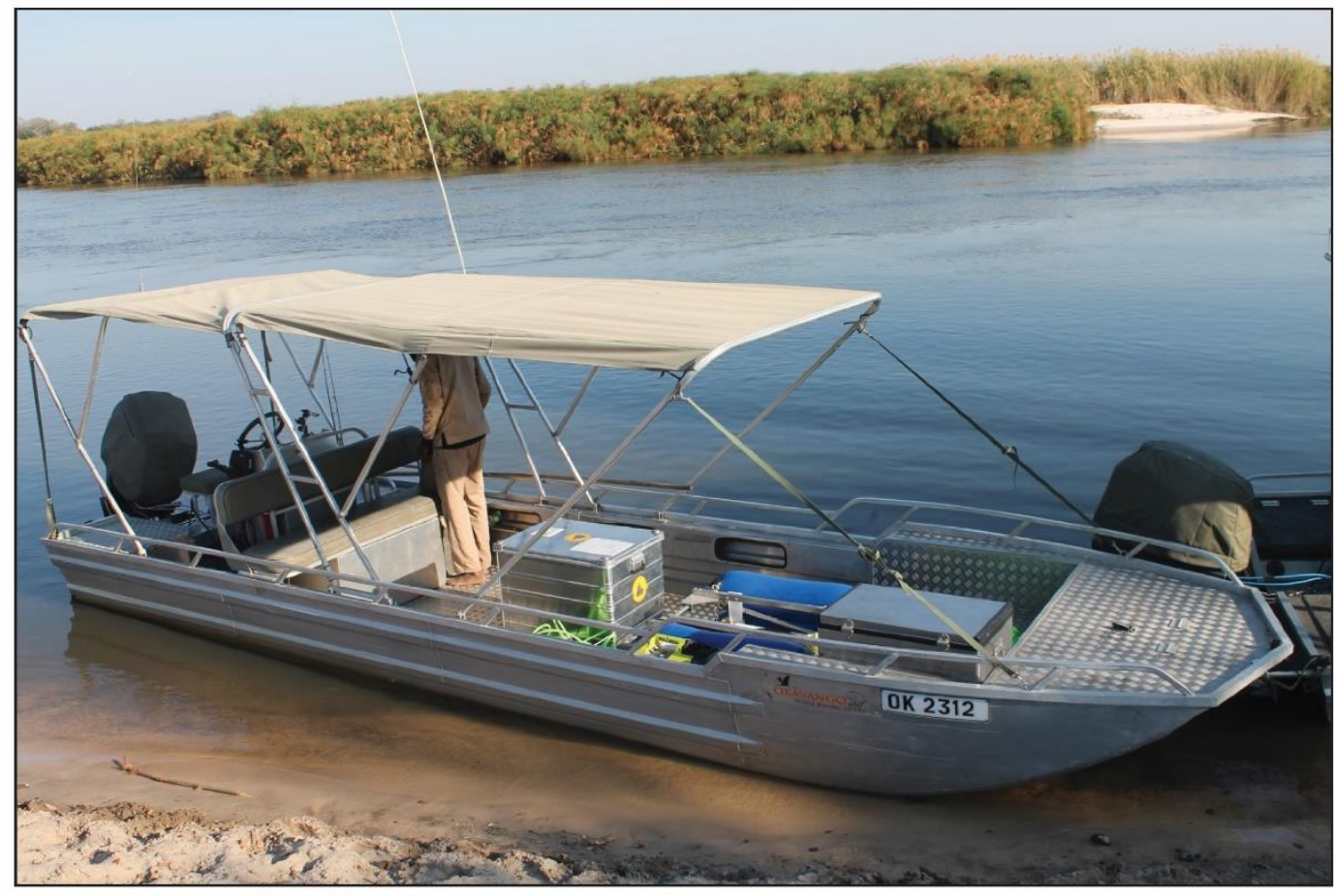




\section{Figure 5}
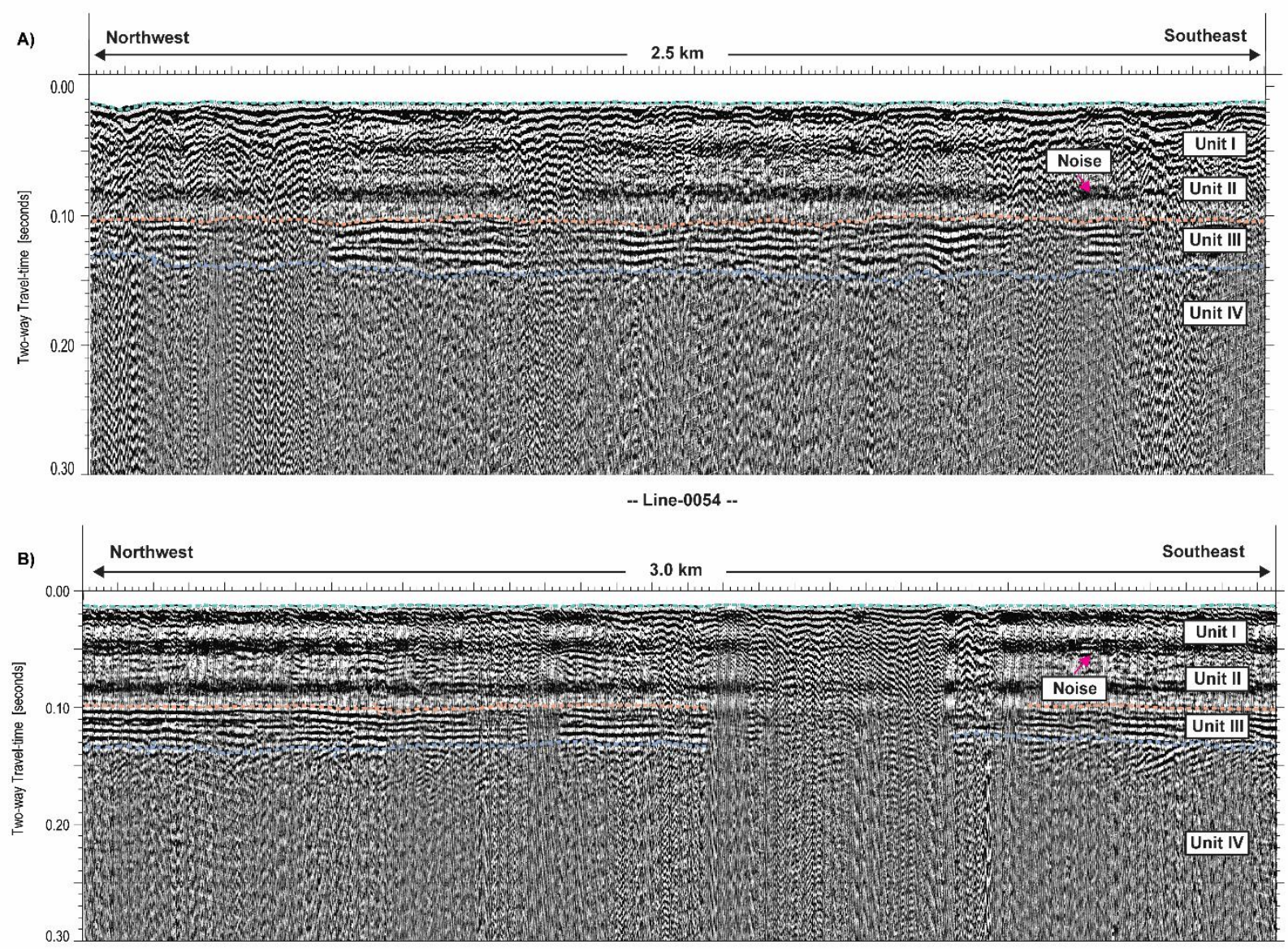

-- Line-0060 -- 


\section{Figure 6}

A)
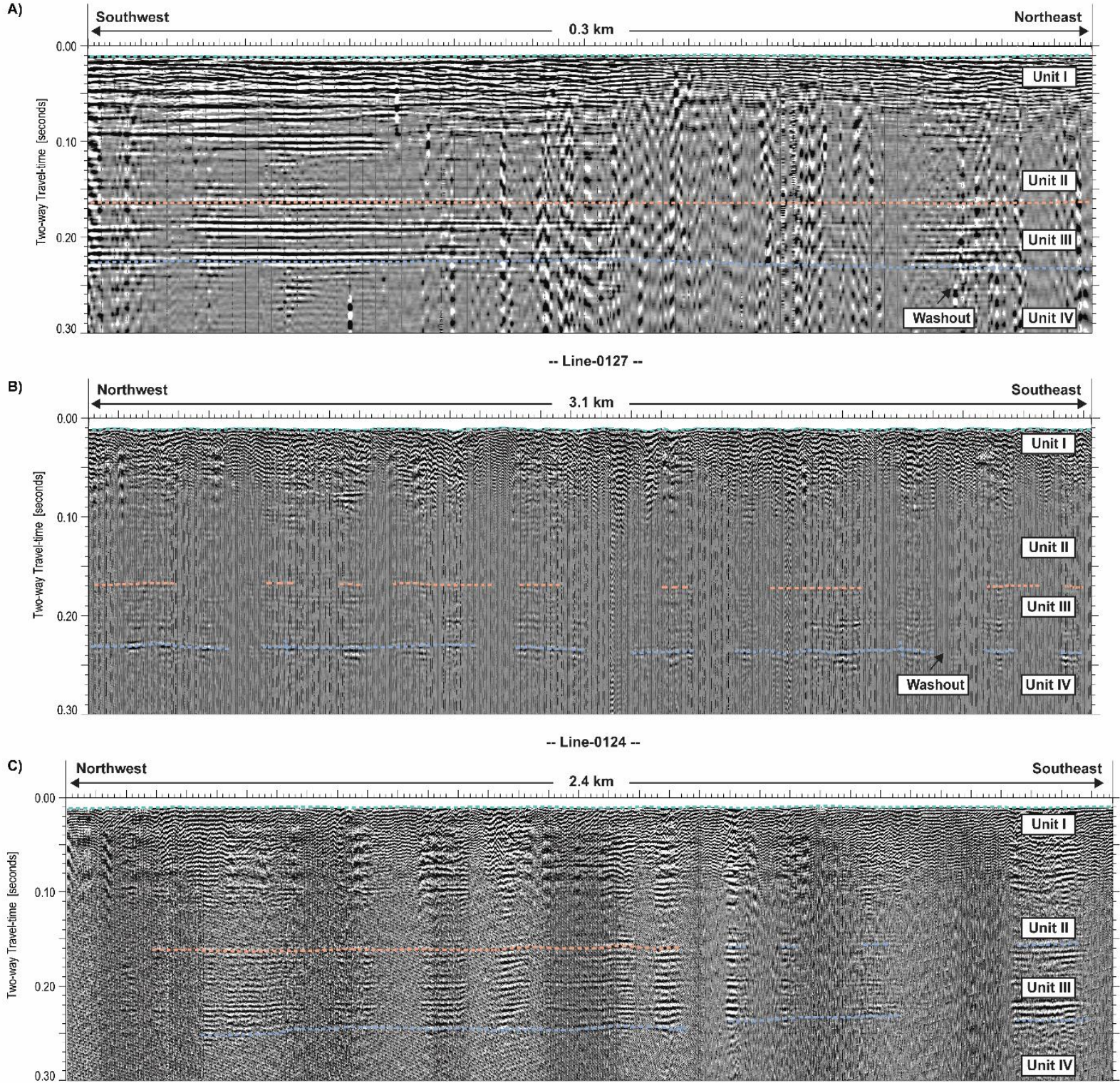

Line-0082 
Figure 7
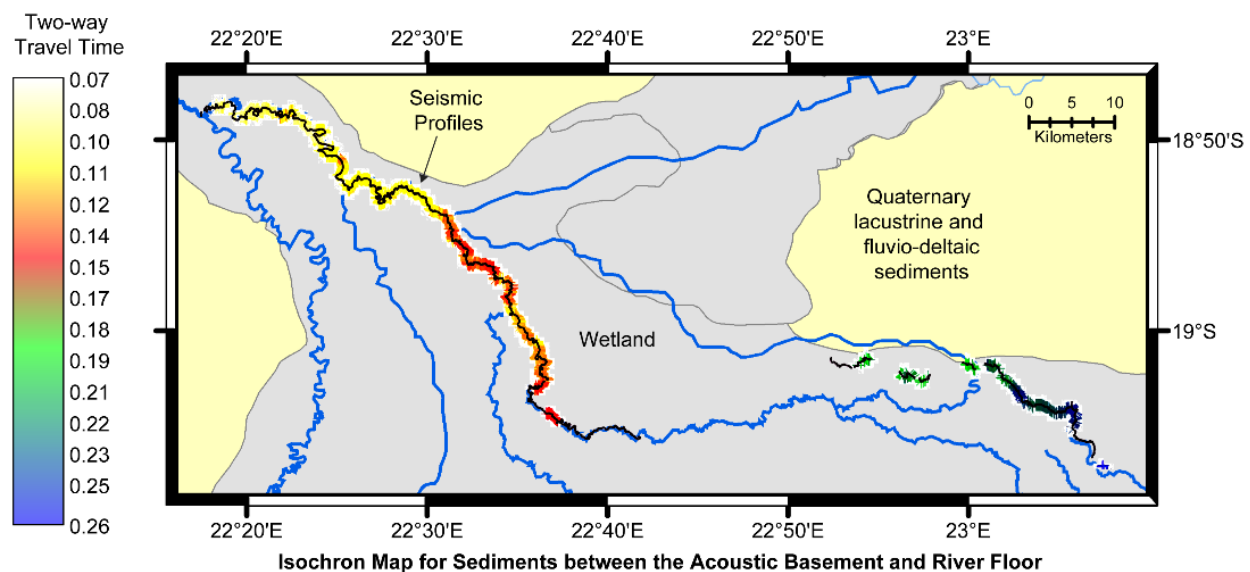

Two-way Travel Time
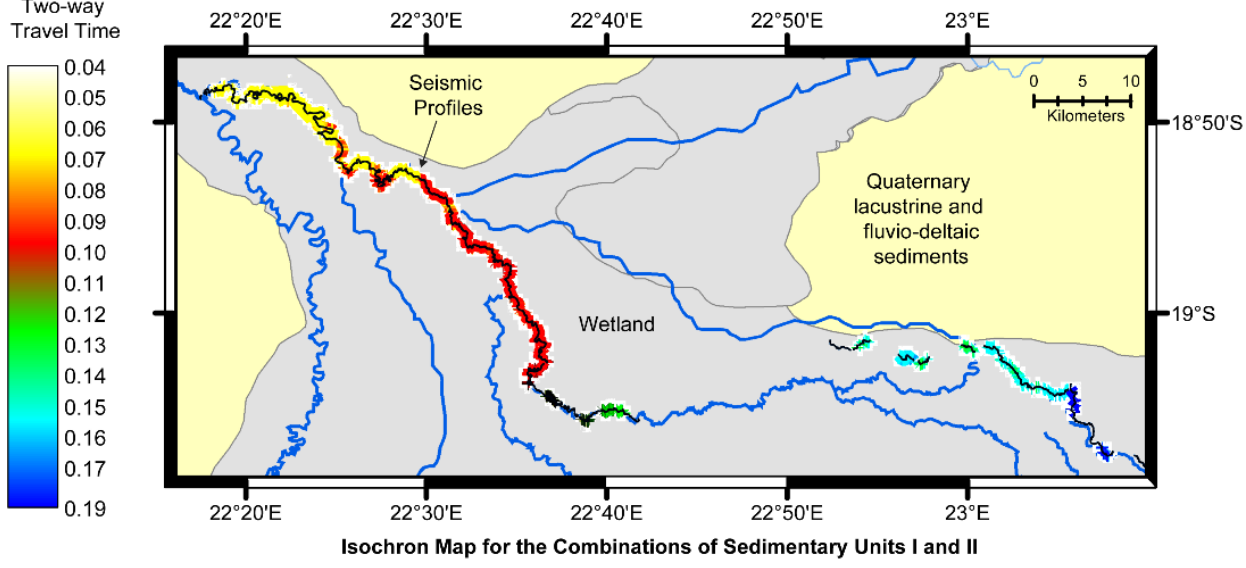

Two-way
Travel Time
\begin{tabular}{|l|l}
\hline & 0.01 \\
0.02 \\
0.03 \\
0.03 \\
0.04 \\
0.05 \\
0.05 \\
0.06 \\
0.06 \\
0.07 \\
0.08 \\
0.08 \\
0.09 \\
0.10 \\
0.11
\end{tabular}

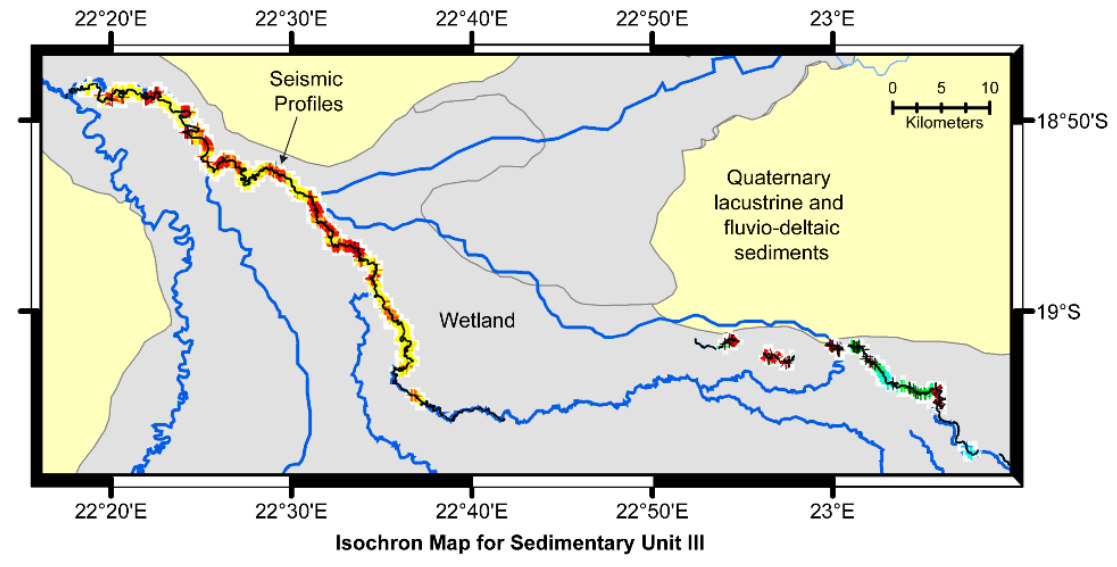


Figure 8

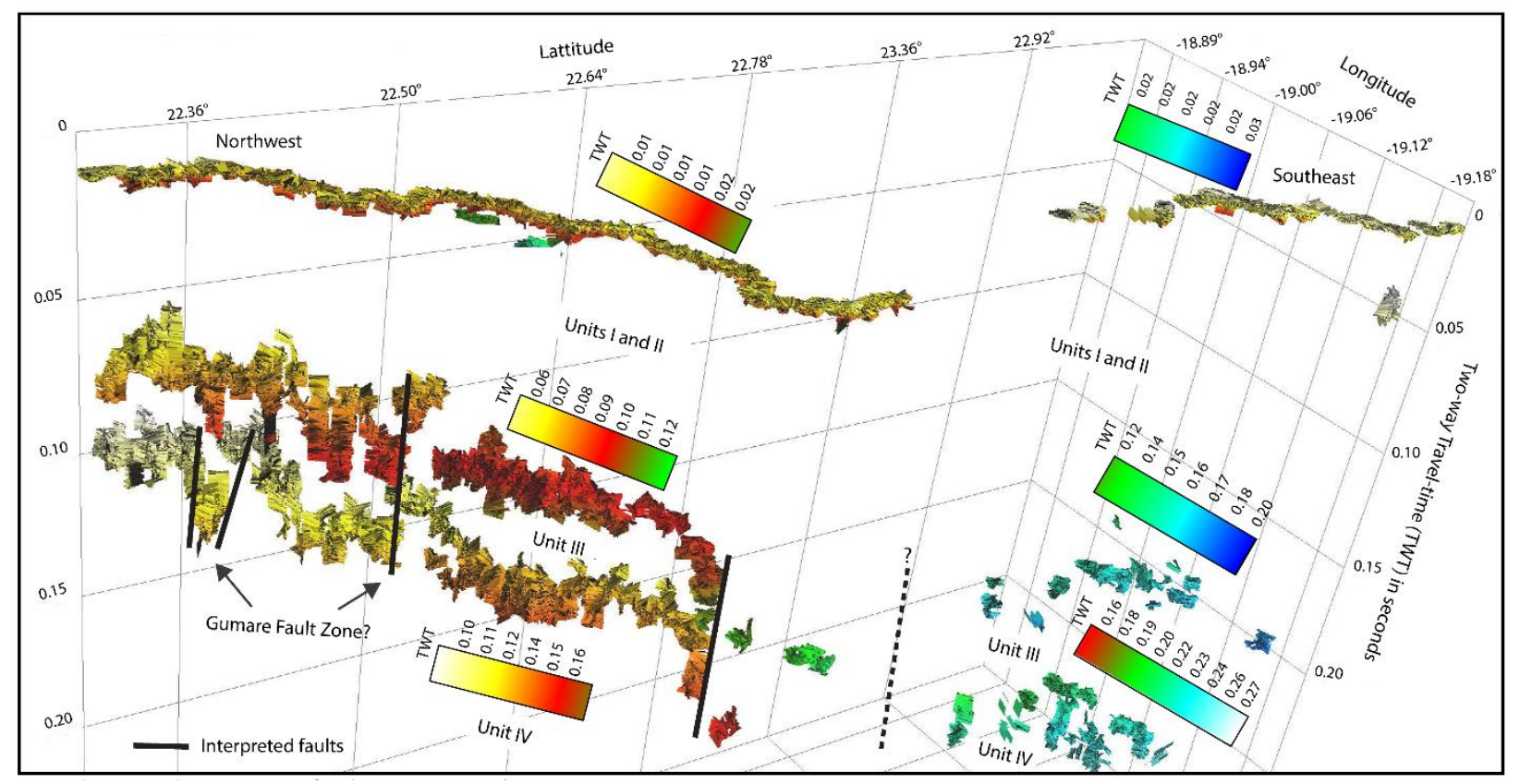

